FEDERAL RESERVE BANK OF SAN FRANCISCO

WORKING PAPER SERIES

\title{
Monetary Policy Spillovers Under Covid-19: Evidence from U.S. Foreign Bank Subsidiaries
}

\author{
Mark M. Spiegel \\ Federal Reserve Bank of San Francisco \\ June 2021 \\ Working Paper 2021-14 \\ https://www.frbsf.org/economic-research/publications/working-papers/2021/14/
}

\section{Suggested citation:}

Spiegel, Mark M. 2021 "Monetary Policy Spillovers Under Covid-19: Evidence from U.S. Foreign Bank Subsidiaries," Federal Reserve Bank of San Francisco Working Paper 2021-14. https://doi.org/10.24148/wp2021-14

The views in this paper are solely the responsibility of the authors and should not be interpreted as reflecting the views of the Federal Reserve Bank of San Francisco or the Board of Governors of the Federal Reserve System. 


\title{
MONETARY POLICY SPILLOVERS UNDER COVID-19: EVIDENCE FROM U.S. FOREIGN BANK SUBSIDIARIES
}

\author{
MARK M. SPIEGEL
}

\begin{abstract}
This paper uses Call Report data to examine the impact of home country monetary policy on foreign bank subsidiary lending in the United States during the COVID-19 pandemic. Examining a large sample of foreign bank subsidiaries and domestic U.S. banks, we find that foreign bank lending growth was positively associated with both lower home country policy rates and negative home country rates. Our point estimates indicate that a one standard deviation decrease in home country policy rates was associated with a 3.5 percentage point increase in lending growth while negative home country policy rates added an additional 3.0 percentage points on average. Disparities in sensitivity to home country rates also exist by bank size, as large banks exhibited more responsiveness to home country policy rate levels, but were less responsive to negative policy rates. Easier home country policy rates are also found to impact negatively in growth in capital ratios and bank income, in keeping with expanded foreign subsidiary activity. However, income responses to negative home country rates are mixed, in a manner suggestive of sophisticated adjustment of global bank balance sheets to changes in relative home and host country monetary policy stances. Overall, our findings confirm that the bank lending channel for global monetary policy spillovers was active during the pandemic crisis.
\end{abstract}

Date: May 25, 2021.

Key words and phrases. Monetary policy, negative interest rates, banking, foreign subsidiaries. JEL classification: G14, G18, G32

Federal Reserve Bank of San Francisco, 101 Market St., San Francisco, CA, Mark.Spiegel@sf.frb.org. Paper prepared for City University of Hong Kong Global Research Unit Conference on Financial Globalization and De-Globalization. I thank Agustin Benetrix, Valeriya Dinger, Jose Lopez, Robert McCauley, Gurnain Pasricha, Helen Popper, and Frank Westermann, for helpful comments. Remy Beauregard and Olivia Lofton provided excellent research assistance. The views expressed in this paper are those of the authors and do not necessarily reflect the views of the Federal Reserve Bank of San Francisco or the Federal Reserve System. 


\section{INTRODUCTION}

The onset of the COVID-19 crisis in the spring of 2020 caused abrupt disruptions to the general financial system. Liquidity dried up, even in treasury and conventional commercial paper markets, and many nonbank institutions, including money markets and hedge funds, experienced deep disruptions. Countering this trend, the U.S. commercial banking system held up surprisingly well, as increased regulatory standards going into the crisis left banks on average entering the pandemic relatively well capitalized and placed to act as a source of stability.

These healthy capital positions at the crisis onset were largely attributable to increased regulatory standards put in place after the global financial crisis of 2007-2009. That crisis also yielded a number of studies demonstrating that multinational bank activity had acted as conduits of home country volatility in the global financial system. Home country liquidity or regulatory changes were seen to influence bank lending activity through their foreign branches and subsidiaries. Optimal management of internal capital induced banks to respond to shocks that left foreign lending more or less attractive by increasing or decreasing their branch and subsidiary activity accordingly [e.g. Cettorelli and Goldberg (2012b) and Berrospide et al. (2017)].

Of course, one major source of foreign bank activity changes during the crisis were home country monetary policy shocks. Foreign bank lending has long been known to respond to cross-country interest differentials [e.g. Goldberg and Saunders (1981)]. The global financial crisis was no exception. Advanced economies abruptly eased home country policy, lowering potential returns on lending domestically. This induced banks from these source countries to increase their foreign lending activity, expanding credit supply in their subsidiaries and in some cases contributing to disruptive surges in capital inflows in those countries [e.g. Cettorelli and Goldberg (2011)].

This paper revisits the question of global monetary policy spillovers through the lens of multinational bank lending during the pandemic. Countries entered the pandemic in different economic situations, which resulted in their entering the crisis under disparate monetary policy stances.

In particular, a number of traditional source country monetary regimes, particularly the euro area and Japan, entered the pandemic with policy rates below the zero bound. This provides the first opportunity to examine global monetary policy spillovers in the context of negative interest rates. ${ }^{1}$ Recent literature has highlighted

\footnotetext{
${ }^{1}$ The prominence of the effective lower bound as a potential constraint for policy during the pandemic period, even for countries under negative policy rates, meant that this period was also
} 
that the reluctance of banks to pay negative rates on retail deposits may result in extra sensitivity to the zero bound in bank responses to home country policy rates [e.g. Altavilla et al. (2018) and Bottero, Minoiu, Peydro, Polo, Presbitero, and Sette (Bottero et al.).$^{2}$ We therefore also examine the possibility of a negative interest rate effect of home country policy rates on the activity of U.S. foreign bank subsidiaries over and above the linear impact of negative rates as a further reduction in policy rates.

In order to isolate the impact of home country monetary policy, we concentrate on bank lending activity in the United States. In particular, we use regulatory filings obtained from the Federal Financial Institutions Examination Council's "Call Reports", which provides detailed information on both balance sheet and income statement variables. Our data set includes both domestic U.S. banks and foreign bank subsidiaries. In particular, we exclude both foreign branches and agencies that are prominent components of a number of previous studies. We do so to mitigate the degree of regulatory disparities across our sample. As noted by a number of recent previous studies [e.g. Bussierè et al. (2021) and Avdjiev et al. (2021)], the overlap of disparities in home and host country monetary and regulatory policies likely affects branches and subsidiaries differently in complex ways. Of course, our methodology can not completely remove all foreign regulatory changes. However, by concentrating on a comparison of foreign subsidiaries and domestic banks alone, with the relatively well-measured U.S. regulatory data, our intent is to assemble the cleanest sample possible in which to examine the responses of foreign banks to disparate home country monetary policies against the benchmark of the activity of their domestic U.S. bank competitors.

Our specification conditions for bank characteristics going into the pandemic based on end 2019 data. We then examine the implications of both home country policy rates and any special sensitivity to negative rates over the most turbulent period of the pandemic, the first half of $2020 .^{3}$ Our regression results demonstrate that

one in which unconventional policy, such asset purchases and forward guidance, were also prevalent. This paper concentrates on policy rates, including the special implications of rates falling below zero, and leaves consideration of such unconventional monetary policies for future work.

${ }^{2}$ Evidence to date on the effects of the zero bound on bank profitability are mixed, as banks have found ways to charge depositors fees and used other non-interest income strategies to offset losses in interest income suffered under low or negative rates. See, for example, Lopez et al. (2020).

${ }^{3}$ As discussed in Lopez and Spiegel (2021), the second half of 2020 exhibited a number of noisy changes in bank balance sheets, particularly adjustments by U.S. banks to borrowers' returning precautionary cash buildups that took place at the onset of the pandemic that result in volatile movements in activity measures. 
home country monetary policy rates had the expected impact on foreign subsidiary lending during the pandemic crisis. Our point estimates suggest that a one standard deviation decrease in home country policy rates was associated with a 3.5 percentage point increase in total bank lending growth over the first half of 2020. Moreover, we also find that having negative rates encouraged lending growth over and above this simple policy rate effect. Our regression coefficient estimates indicate that even after conditioning for policy rate levels, banks with negative home country interest rates had 3 percentage points additional growth in lending on average.

We also examine differences across our sample by bank size. We divide our base sample into two sub-samples: Small and medium-sized banks and large banks. We find that large banks were more sensitive than their small and medium-sized counterparts to home country policy rates during the pandemic. Our regression coefficient estimates indicate that the same decline in home country policy rates would only be associated with a 1.8 percentage point increase in lending growth, while it would be associated with a 6.2 percentage point increase among our large bank sub-sample.

In contrast, we find that small and medium-sized banks were more sensitive to negative home country policy rates. Our regression point estimates indicate that small banks from countries with negative home policy rates on average had 12 percentage points greater lending growth over the first half of 2020, while our estimated coefficient for the large banks in our sample was actually negative and only significant at a $10 \%$ confidence level. However, combined with the stronger policy rate coefficient estimates we obtained for large banks in our base specification, our results are better taken as indicative that large banks are less encouraged to expand lending through home country movements into negative policy rate territory than their small and medium counterparts.

Both of these results are in keeping with our understanding of the greater overall flexibility of large multinational banks. Large banks are likely more responsive to home country policy rates than small banks because they are better-placed to act as conduits for expanding U.S lending in response to lower home country policy rates, and vice versa in terms of higher rates. Similarly, large banks are probably also more adept at shifting their funding sources away from deposits as policy rates breach the zero lower bound, and so need to respond in terms of moving internal firm capital abroad to the U.S. less than their small bank counterparts.

We also consider the implications of home rates for growth in the important component of small business and farm lending during the pandemic. Our results are more 
mixed here, as negative home country rates are found to have a significant positive impact on both small business and small farm lending growth, although our coefficient estimates indicate a much larger impact on small business lending growth. We also find a predicted negative, but insignificant, impact of home country rates on small farm lending growth.

Finally we consider the implications of home policy rates for foreign subsidiary capital growth and income growth during the pandemic. As our lending results indicate, both policy rate levels and movement of policy rates across the zero bound were found to induce foreign bank subsidiaries to increase their activities in the United States. We would therefore expect lower and negative policy rates to be associated with decreased bank capital asset ratios and income.

Our results below confirm this outcome for bank capital ratios, but those for income ratios are mixed. While we find that easier home country policy rates do encourage higher subsidiary income growth, the results for negative rates are close to zero. As we discuss below, these results are suggestive of the complicated funding and revenue options available to foreign bank subsidiaries.

Overall, our results confirm that global spillovers to monetary policy through bank lending that were identified to play a role during the global financial crisis were alive and well during the pandemic. Home country policy rates were negatively associated with lending activity of U.S. foreign bank subsidiaries during the turbulent early days of the COVID-19 pandemic, and the expanded lending responses to easier monetary policies at home resulted in reduced bank capital asset ratios and expanded bank income.

The remainder of the paper is structured as follows. Section II provides a review of the literature on global banks and monetary policy spillovers. Section III provides details on our data set and describes our base specification. Section IV reviews our base specification results. Section V examines heterogeneity in our results with samples split by bank size and for the special case of small business and farm lending growth. Section VI examines the impact of home country monetary policy on bank capital asset ratios and income. Lastly Section VII concludes.

\section{LITERATURE REVIEW}

This paper is related to a number of themes in the existing literature. First, there is a large literature associated with global spillovers to bank lending, beginning with the seminal work by Peek and Rosengren (1997) showing that country shocks can lead to 
reduced lending activity abroad by foreign banks (e.g. Peek and Rosengren (1997)). In particular, bank lending has long been known to respond to interest differentials. For example, Goldberg and Saunders (1981) pool U.S. foreign bank subsidiaries, branches and agencies in a panel from 1972 through 1979 and demonstrate that foreign bank activity was dependent on interest differentials between home country and U.S. deposits and loans. Similarly, Cettorelli and Goldberg (2012a) demonstrate that international lending patterns across global banks are responsive to U.S. monetary policy shocks in a manner that result in global monetary policy spillovers. More recently, Buch et al. (2019) report on a 17 country study that demonstrates spillovers from major source countries, such as the euro area, Japan, the U.K. and the U.S. into bank lending outside of those jurisdictions.

Our study is also related to the literature on counter-cyclical foreign bank lending. There has been some speculation that foreign bank lending in the United States during recessions has played a stabilizing role, by expanding lending while US banks, challenged by balance sheet losses related to the recession, retrench. However, more recent studies have shed doubt that foreign banks play an important counter-cyclical role. In particular, Rai et al. (2021) find mixed results for foreign subsidiaries and branches in lending during the 1990-1991, 2000, and 2007-2009 recessions, and conclude that domestic factors also dominate foreign bank lending patterns. Kleimeier et al. (2013) demonstrate that foreign bank deposits and lending exhibit different dynamics prior to the onset of a crisis, so that net and gross lending dynamics can differ substantially.

Differences in lending practices between foreign subsidiaries and host country banks have also been identified in the literature, even under normal circumstances. Houston et al. (2012) demonstrate that global banks respond to heavy regulation at home by transferring funds to less-regulated foreign subsidiaries where they are able to engage in more risk lending practices. Ashraf and Arshad (2017) demonstrate that lending practices of foreign affiliates of global banks more deeply reflect their home country cultures than those in their host country. di Giovanni et al. (2018) demonstrate that firms pay a lower rate of interest when borrowing in foreign currency from domestic banks than foreign banks.

Our work is also related to the literature on how financial crises influence global monetary spillovers, and in particular the impact of the 2007-2009 global financial crisis on the lending channel for monetary policy spillovers. Cettorelli and Goldberg (2011) find that global bank dollar funding vulnerability affected lending responses 
to emerging market countries during the global financial crisis. Demirgüç-Kunt et al. (2017) examine loan-level data from 1995-2015 over 124 countries and find that lower interest rates does encourage greater cross-border lending in the syndicated loan market.

A number of studies observed disproportionate retrenchment by foreign banks during the global financial crisis. Acharya et al. (2017) show that during the 2007 commercial paper freeze foreign banks faced unique challenges in raising alternative dollar funding to their domestic US bank counterparts who were able to adjust more easily through a variety of channels, most notably through raising additional deposits and through interbank borrowing. Most confirm a home country channel whereby home country financial crises lead banks to cut their credit extension more heavily than their domestic counterparts [e.g. Dekle and Lee (2015) and Ongena et al. (2015)]. Albertazzi and Bottero (2014) demonstrate that foreign banks operating in Italy in the wake of the Lehman collapse restricted lending in that country more aggressively than domestic Italian counterparts.

Our framework used also serves to address issues associated with the interplay of monetary policy spillovers and home and host country macro-prudential policies. Avdjiev et al. (2021) examine the interplay of home and host regulation and home and host monetary policy in the determination of global bank lending. They find that the impact of US monetary policy on foreign bank lending is influenced by prudential policies abroad. In particular, tighter US monetary policy results in greater sensitivity of the foreign lending to host country prudential policies, such as exposure limits and capital requirements. Similarly, Takáts and Temesvary (2019) control for demand conditions by evaluating (for example) dollar-denominated lending from the UK to Malaysia to isolate identified isolated monetary policy shocks from macro-prudential policy. They confirm that monetary policy tightening is associated with reduced supply of lending in that currency.

Our results are also related to the large literature on the impact of low and negative rates on banking activity. Borio and Gambacorta (2017) find that bank lending becomes less responsive to reductions in policy rates as they approach zero. Demiralp et al. (2019) demonstrate that negative rates are more challenging for small banks that are likely to be deposit dependent. Ulate (2021) finds that policy rate cuts under negative interest rates induce smaller lending responses than under low positive rates. 
Finally, a number of papers are beginning to emerge examining bank lending patterns under the COVID-19 virus. Hardy and Takáts (2020) examine a panel of international banks and demonstrate that global borrowing was more prevalent among countries stronger economic activity and lower financial vulnerability, while banks from countries with better-capitalized banking systems were more prevalent as lenders. Berger, Bouwman, Norden, Roman, Udell, and Wang (Berger et al.) examine how relationship banking progressed over the course of the pandemic. Li and Strahan (2020) and Lopez and Spiegel (2021) examine small business lending under the COVID-19 crisis, and the role played by the Paycheck Protection Program (PPP) program. Anbil, Carlson, and Styczynski (Anbil et al.) demonstrate that the Federal Reserve Paycheck Protection Program Lending Facility was successful in encouraging banks to book a greater share of their lending through the PPP program.

\section{Methodology}

III.1. Data and variable definitions. We use quarterly bank-level regulatory filings obtained from the Federal Financial Institutions Examination Council's "Call Reports", which provides detailed information on both balance sheet and income statement variables. All data is measured as quarter-end. We use 2019Q4 data to characterize bank conditions going into the pandemic and 2020Q2 data to changes in bank characteristics over the course of the pandemic. As Call Report data is compulsory for regulated banks in the United States, including foreign bank subsidiaries, this data source has no issues concerning potential endogeneity in reporting patterns. ${ }^{4}$

Our sample is a cross-section of U.S. commercial banks. We separate reporting banks into three groups based on asset size in 2019Q4; small banks with assets below $\$ 10$ billion, large banks with assets exceeding $\$ 100$ billion, and a middle category between them. Our base specification contains 4,090 banks, of which 3,376 are classified as small banks, 584 are medium-size banks, and 130 classified as large banks. We designate as foreign all banks listed in the Federal Reserve Board Structure and Data for the U.S. Offices of Foreign Banking Organizations. ${ }^{5}$ All foreign banks in our sample are listed in Appendix Table A1.

\footnotetext{
${ }^{4}$ Even though reporting is compulsory, some banks do report with a lag and the size of recent Call Report data, such as that used in this study, can grow slowly over time.

${ }^{5}$ By construction, this definition includes 6 banks that we classify as under the same monetary regime as the United States: U.S. territories, including Guam and Puerto Rico, as well as banks from the Cayman Islands, who run a currency board pegged to the U.S. dollar. Their home country policy rates are therefore set to equal those prevailing in the U.S.
} 
Our dependent variables are primarily measures of growth in the lending metric "total loans and leases" in the Call Report between 2019Q4 and 2020Q2 at the bank level. We label this variable $L E N D G R W T H$. We also examine growth in small business and farm lending, which we refer to as BLGRWTH and FLGRWTH respectively, and two measures of changes in bank capital ratios, growth in total capital ratios and tier 1 risk-adjusted capital ratios, which we label TCAPGRWTH and $T 1 R A G R W T H$ respectively. Finally we examine bank income growth over the period, both in terms of total income growth, NIGRWTH and its main components, net interest income growth $(N I I G R W T H)$ and net non-interest income growth NNIGRWTH. As growth measures often exhibit extreme outliers over short time horizons (and indeed do in this data set), we winsorize all of the growth variables at the $5 \%$ level.

The variables of interest are POLRATE, and measure of foreign short-term policy rates, and NEGI, a dummy variable that takes value 1 if a bank's home country policy rate is less than zero, and 0 otherwise. Because banks would be predicted to respond to real, rather than nominal, interest rate differentials, we adjust for home country inflation using the change in the CPI (CPIGRWTH).

We examine growth in bank lending over this period while conditioning for differences in individual bank characteristics going into the crisis. Conditioning for disparities in bank characteristics is potentially important, as, for example, Cornett et al. (2011) demonstrated that during the global financial crisis financial constraints inhibited credit expansion by banks. We follow the literature, such as Rice and Rose (2016) and Li and Strahan (2020), in the determination of Call Report conditioning variables to include in our specification, and use pre-pandemic 2019Q4 values. We include $L O A N C O M$ as a measure of outstanding loan commitments, which have been shown to play a major role in encouraging lending during the COVID crisis (e.g. Greenwald et al. (2020)). We also include COREDEP, which measures core deposits relative to total assets as a measure of a banks' reliance on deposit funding. We include $C O R E D E P$, which measures core deposits relative to total assets as a measure of a banks' reliance on deposit funding, and LIQASSET, which measures bank cash and security holdings as a share of total assets, as a measure of bank liquidity. We also include the total capital asset ratio $T C A P$, to capture bank capital positions. Finally, as a number of banks experienced exceptionally large changes in their funding composition over this period, we also include a variable CHGCOREDEP to condition for changes in the share of core deposit funding between 2019Q4 and 2020Q2. 
TABLE 1. Summary statistics

\begin{tabular}{lcccccccc}
\hline \hline & \multicolumn{4}{c}{ Foreign subsidiaries } & \multicolumn{4}{c}{ US banks } \\
& mean & sd & $\min$ & $\max$ & mean & sd & $\min$ & $\max$ \\
\hline LENDGRWTH & 0.07 & 0.09 & -0.04 & 0.36 & 0.10 & 0.10 & -0.04 & 0.36 \\
T1RACAP & -0.06 & 0.09 & -0.34 & 0.10 & -0.05 & 0.07 & -0.75 & 1.03 \\
POLRATE & 0.33 & 0.88 & -0.75 & 4.00 & 0.13 & 0.00 & 0.13 & 0.13 \\
NEGI & 0.28 & 0.46 & 0.00 & 1.00 & 0.00 & 0.00 & 0.00 & 0.00 \\
LGBANK & 0.41 & 0.50 & 0.00 & 1.00 & 0.03 & 0.16 & 0.00 & 1.00 \\
LOANCOM & 0.06 & 0.10 & 0.00 & 0.47 & 0.04 & 0.15 & 0.00 & 9.55 \\
COREDEP & 0.78 & 0.13 & 0.03 & 0.90 & 0.84 & 0.06 & 0.06 & 0.97 \\
LIQASSET & 0.16 & 0.22 & 0.01 & 0.98 & 0.09 & 0.09 & 0.00 & 0.94 \\
TCAP & 0.16 & 0.12 & 0.09 & 0.94 & 0.12 & 0.03 & 0.03 & 0.60 \\
CHGCOREDEP & 0.00 & 0.04 & -0.11 & 0.07 & -0.00 & 0.04 & -0.62 & 0.45 \\
CPIGRWTH & 0.29 & 1.29 & -1.22 & 5.20 & 0.36 & 0.00 & 0.36 & 0.36 \\
\hline Observations & 46 & & \multicolumn{1}{c}{4044} & & & \\
\hline \hline
\end{tabular}

See text for variable definitions.

Summary statistics for our variables of interest subsequent to winsorizing at the $5 \%$ level are shown in Table 1 . Our data set exhibits a healthy degree of variability in our base specification dependent variable, growth in total loans and leases. On average, total loans and leases grew rapidly during the pandemic, with total values ranging from approximately -4 percentage points to positive 36 percentage points for both domestic and foreign banks.

As discussed in the introduction, our methodology of pooling U.S. foreign branch subsidiaries with domestic U.S. banks has the advantage of harmonizing the regulatory regime under which these banks are operating as much as possible, thereby serving to isolate the effects of home country policy rate differentiation and negative policy rates. However, Table 1 also reveals the cost of such a strategy. Our sample has a relatively small number of foreign banks (46). Nevertheless, as shown in Appendix Table A1, these subsidiaries represent a number of important foreign financial institutions hailing from a wide variety of original jurisdictions.

The foreign subsidiaries also represent a wide variety of home country policy rates. See Figure 1. Foreign subsidiaries in our sample are divided into 5 bins, each column representing population counts of spreads of 100 basis points in policy rates. The left 
Figure 1: Foreign policy rates in 2020Q2

30

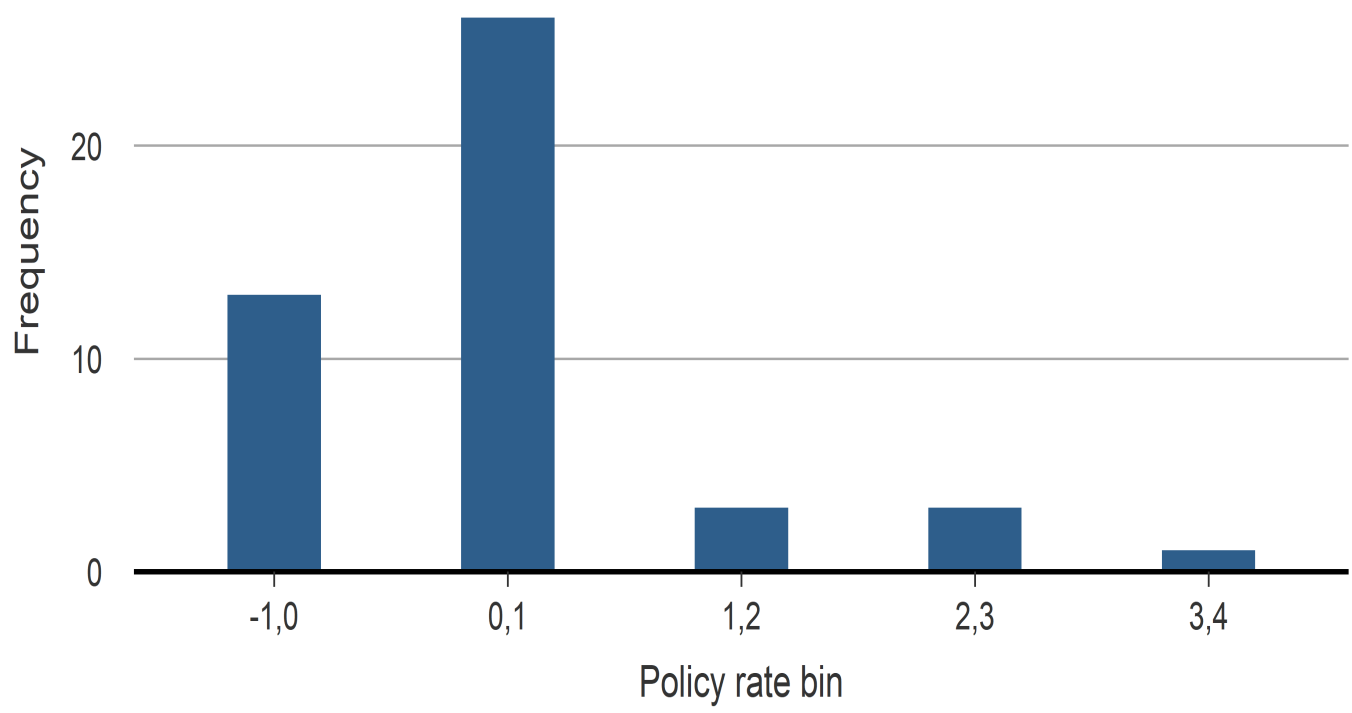

Figure 1. Populations of 100 basis point bins for foreign subsidiaries in sample. Left column represents population of banks with home country rates from -1.0 to 0.0 , and so on. See text for details.

column represents the 13 banks in our sample with rates ranging from -1.0 to 0.0, while the second column represents the 26 banks with policy rates ranging from 0.0 to 1.0 . The U.S. policy target of 0.125 at this time would fall in this range. The remaining three columns represent 7 foreign subsidiaries with home country rates exceeding 1.0.

As shown in Figure 2, these populations correspond to healthy variation in home country policy rates, vis-a-vis other foreign subsidiaries and the U.S. policy rate benchmark. The policy rates prevailing in the 13 foreign subsidiaries with negative home country rates averaged -0.37 , while those for the 33 banks with 0 or positive policy rates averaged 0.58. As such, our sample include foreign bank subsidiaries with home country policy rates both substantially above and below the policy rate prevailing in the United States.

III.2. Specification. Our base specification estimates our cross-section of banks using ordinary least squares:

$$
L E N D G R W T H_{i}=c+\beta_{1} P O L R A T E_{i}+\beta_{2} N E G I_{i}+\beta X_{i}+U S B A N K_{i}+\epsilon_{i}
$$


Figure 2: Average policy rates in 2020Q2

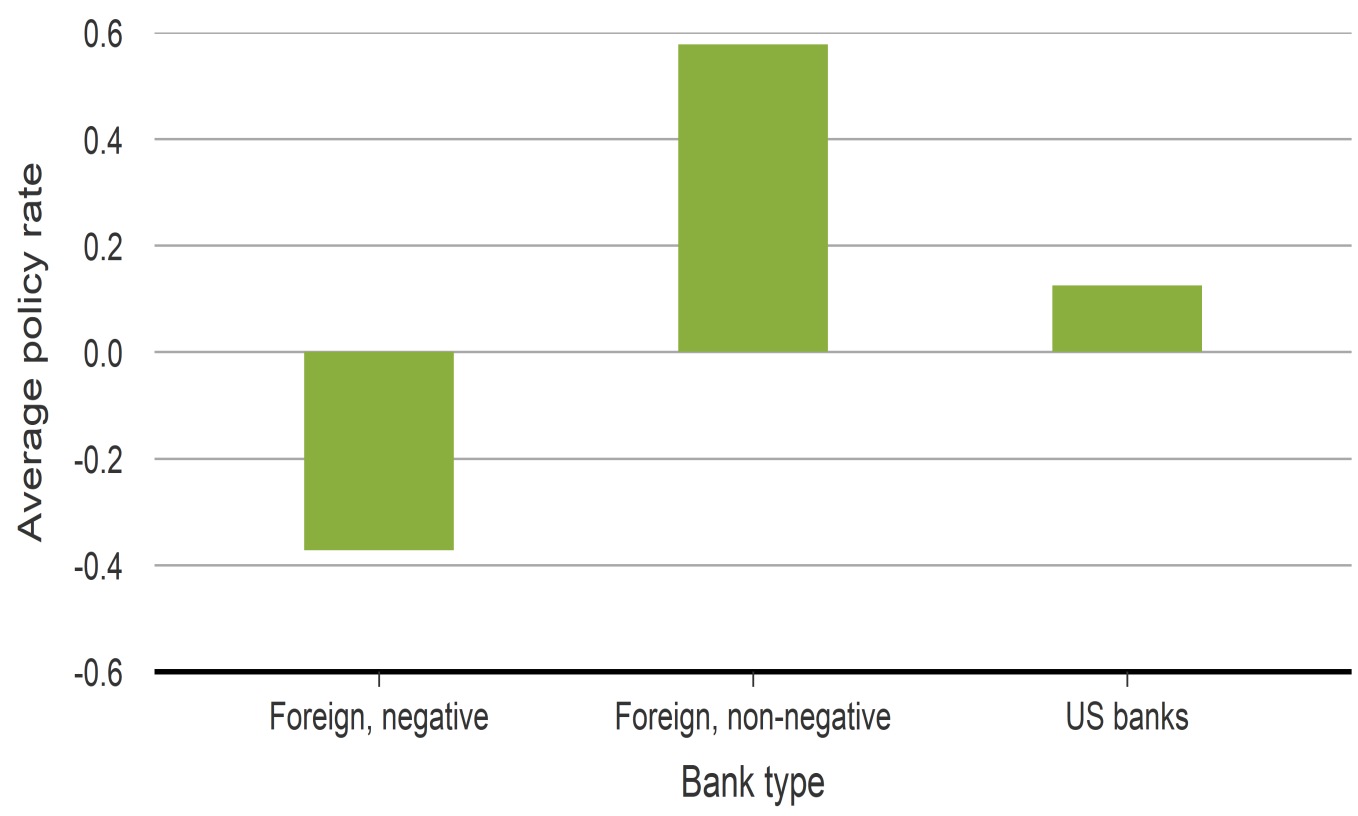

Figure 2. Average home country policy rates. First column shows average rates among foreign subsidiaries with negative home policy rates, second column with poisitive rates, and third column show U.S. benchmark policy rates target.

where POLRATE $E_{i}$ and $N E G I_{i}$ are our variables of interest for bank $i$, representing home country policy rates and a 0-1 dummy indicating whether or not the home country policy rate is negative. $X_{i}$ denotes the set of conditioning variable discussed above, $U S B A N K_{i}$ is a 0-1 dummy identifying US banks, and $\epsilon_{i}$ represents the regression residual, with standard errors clustered into domestic bank and foreign subsidiary sub-groups.

\section{Results}

Our results are shown in Table 2. Column 1 displays our base specification, including both of our variables of interest. It can be seen that both of these variables of interest enter significantly with their predicted signs, negative for POLRATE and positively for NEGI, at more than a $1 \%$ confidence level. Our point estimates also indicate that these programs have had economically meaningful impacts on lending. Combined with the summary statistics in Table 1 they imply that a one standard deviation decrease in home country policy rates is associated with a 3.5 percentage point increase in growth in total loans and leases. Moreover, our positive point estimate 
for negative policy rates implies that banks from countries with negative policy rates experienced a 3.0 percentage point additional increase on average in lending over this period. Finally, we also obtain a positive and significant coefficient on CPIGRWTH, as expected, at a $5 \%$ confidence level, indicating that banks responded to real interest rate differentials in their lending under the COVID-19 crisis.

Among our conditioning variables, we obtain positive and significant results at a $1 \%$ confidence level for $L O A N C O M$ and negative and significant results at the $1 \%$ level for $T C A P$. In the case of $L O A N C O M$, this is in keeping with expectations, as banks that entered 2020 with greater levels of unused loan commitments would all else equal have been called upon to provide more liquidity at the onset of the crisis as firms scrambled to lock in reserves of liquid assets. We have less certainty about what coefficient estimate should have been expected for TCAP. On one hand, firms with higher capital asset ratios would be better-placed during the pandemic to increase their lending activity. However, those very banks are also banks that were pursuing a less aggressive strategy going into the crisis, and it is unclear that they would be willing to extend these additional available funds.

We also obtain negative and significant coefficient estimates at a $5 \%$ confidence level for COREDEP , CHGCOREDEP, indicating that deposit-intensive and banks with higher growth in their shares of core deposit funding had lower increases in their overall lending activity. These results also seem in keeping with more conservative behavior among these banks. LIQASSET is insignificant, as is our dummy variable identifying large banks. However, our dummy variable for U.S. banks is positive and significant at a $10 \%$ confidence level. Our coefficient point estimate indicates that holding all else constant, U.S. banks had 3.0 percentage points higher lending growth over the COVID-19 period than their foreign subsidiary counterparts.

Columns 2 and 3 repeat our base specification with the variables of interest entered individually. This raises the absolute value of our estimated coefficients, as the estimate on POLRATE falls from -0.04 to -0.05 while that on NEGI doubles from 0.03 to 0.06 . Overall though, the qualitative takeaway from the robustness checks is that both home country policy rates and negative policy rates play a role in the determination of bank foreign subsidiary lending behavior in the United States over this period.

Finally, to demonstrate that our results are not driven by our conditioning variables for individual bank characteristics, we drop them in columns 4 through 6 . Column 4 includes both of our variables of interest, while columns 5 and 6 introduce them 
TABLE 2. Base specification results

Dependent variable: LENDGRWTH

(1)

(2)

(3)

(4)

(5)

(6)

VARIABLES

\begin{tabular}{|c|c|c|c|c|c|c|}
\hline POLRATE & $\begin{array}{c}-0.04^{* *} \\
(0.01)\end{array}$ & $\begin{array}{c}-0.05^{* *} \\
(0.02)\end{array}$ & & $\begin{array}{c}-0.03^{* * *} \\
(0.01)\end{array}$ & $\begin{array}{c}-0.04^{* * *} \\
(0.01)\end{array}$ & \\
\hline NEGI & $\begin{array}{l}0.03^{*} \\
(0.05)\end{array}$ & & $\begin{array}{c}0.06^{* *} \\
(0.04)\end{array}$ & $\begin{array}{c}0.02^{* * *} \\
(0.00)\end{array}$ & & $\begin{array}{c}0.04^{* * *} \\
(0.00)\end{array}$ \\
\hline LGBANK & $\begin{array}{l}-0.00 \\
(0.64)\end{array}$ & $\begin{array}{l}-0.00 \\
(0.63)\end{array}$ & $\begin{array}{c}0.00 \\
(0.69)\end{array}$ & $\begin{array}{c}-0.02^{* *} \\
(0.05)\end{array}$ & $\begin{array}{l}-0.02^{*} \\
(0.05)\end{array}$ & $\begin{array}{c}-0.02^{* *} \\
(0.03)\end{array}$ \\
\hline LOANCOM & $\begin{array}{c}0.03^{* * *} \\
(0.00)\end{array}$ & $\begin{array}{c}0.03^{* * *} \\
(0.00)\end{array}$ & $\begin{array}{c}0.03^{* * *} \\
(0.00)\end{array}$ & & & \\
\hline COREDEP & $\begin{array}{c}-0.08^{* *} \\
(0.05)\end{array}$ & $\begin{array}{c}-0.08^{*} \\
(0.05)\end{array}$ & $\begin{array}{c}-0.08^{*} \\
(0.06)\end{array}$ & & & \\
\hline LIQASSET & $\begin{array}{c}0.05 \\
(0.20)\end{array}$ & $\begin{array}{c}0.05 \\
(0.21)\end{array}$ & $\begin{array}{c}0.05 \\
(0.22)\end{array}$ & & & \\
\hline TCAP & $\begin{array}{c}-0.33^{* * *} \\
(0.00)\end{array}$ & $\begin{array}{c}-0.33^{* * *} \\
(0.01)\end{array}$ & $\begin{array}{c}-0.33^{* * *} \\
(0.00)\end{array}$ & & & \\
\hline CHGCOREDEP & $\begin{array}{c}-0.67^{* *} \\
(0.01)\end{array}$ & $\begin{array}{c}-0.67^{* *} \\
(0.01)\end{array}$ & $\begin{array}{c}-0.67^{* *} \\
(0.01)\end{array}$ & & & \\
\hline CPIGRWTH & $\begin{array}{c}0.02^{* *} \\
(0.02)\end{array}$ & $\begin{array}{c}0.02^{* *} \\
(0.03)\end{array}$ & $\begin{array}{c}0.01^{* *} \\
(0.03)\end{array}$ & $\begin{array}{c}0.02 * * * \\
(0.01)\end{array}$ & $\begin{array}{c}0.02^{* * *} \\
(0.00)\end{array}$ & $\begin{array}{c}0.01^{* * *} \\
(0.00)\end{array}$ \\
\hline USBANK & $\begin{array}{c}0.03^{* *} \\
(0.02)\end{array}$ & $\begin{array}{l}0.01 * \\
(0.08)\end{array}$ & $\begin{array}{c}0.04^{* *} \\
(0.02)\end{array}$ & $\begin{array}{c}0.02^{* *} \\
(0.02)\end{array}$ & $\begin{array}{c}0.02^{* *} \\
(0.03)\end{array}$ & $\begin{array}{c}0.04^{* * *} \\
(0.00)\end{array}$ \\
\hline Constant & $\begin{array}{c}0.17^{* *} \\
(0.01)\end{array}$ & $\begin{array}{c}0.18^{* * *} \\
(0.01)\end{array}$ & $\begin{array}{c}0.16^{* *} \\
(0.02)\end{array}$ & $\begin{array}{c}0.08^{* * *} \\
(0.01)\end{array}$ & $\begin{array}{c}0.08^{* * *} \\
(0.01)\end{array}$ & $\begin{array}{c}0.06^{* * *} \\
(0.00)\end{array}$ \\
\hline Observations & 4,090 & 4,090 & 4,090 & 4,090 & 4,090 & 4,090 \\
\hline R-squared & 0.09 & 0.09 & 0.09 & 0.00 & 0.00 & 0.00 \\
\hline
\end{tabular}

$\mathrm{P}$ value in parenthesis

Note: Ordinary least squares estimation of impact of home country policy rates on growth in total loans and leases from 2019Q4 through 2020Q2. Standard errors clustered into domestic and foreign subsidiary subgroups. See text for variable definitions. $\mathrm{P}$ values in parenthesis *** $\mathrm{p}<0.01 ; * * \mathrm{p}<0.05 ;{ }^{*} \mathrm{p}<0.1$

individually. It can be seen that our variables of interest continue to enter at a $1 \%$ confidence level with their predicted signs, although there is a modest amount of attenuation in our coefficient point estimates when the conditioning variables are 
excluded. Still, our conclusion is that our results are robust to the exclusion of our conditioning variables.

\section{Robustness CHECKS}

V.1. Sample split by bank size. As large global banks are quite unique in their overall business model to more standard deposit-taking banks, we investigate the robustness of our results to separating our sample by size. We split the sample into a sub-group of small and medium-sized banks, with less than $\$ 10$ billion in total assets, and a subset of large banks with total assets exceeding or equal to $\$ 10$ billion. As before, we first run our specification with both variables of interest, and then repeat one at a time with each variable of interest entered individually.

Our results are shown in Table 3. Columns 1 through 3 run our base specification for the small and medium-sized sub-sample, while columns 4 through 6 examines the large bank sub-sample. Our small and medium-sized sub-sample contains the bulk of our total sample, comprising 3,960 observations of our 4,090 full sample specification. It is therefore no surprise that our results for small and medium-sized banks are qualitatively similar to those in our full sample. Both POLRATE and NEGI continue to enter with their expected negative and positive coefficient estimates respectively, here at a $5 \%$ significance level for both variables. There is some attenuation in the POLRATE variable, but our point estimate on the NEGI variable is much larger. Among small and medium-sized banks, our point estimate suggests that after conditioning for differences in individual bank characteristics banks with negative home country policy rates exhibited 12 percentage points higher growth in lending than those from countries with positive policy rates.

However, we obtain qualitatively different results for our large bank sub-sample in columns 4 through 6 . This sample is far smaller, with only 130 observations in total.

In our base specification with both variables of interest included, we continue to obtain a negative and statistically significant coefficient estimate on POLRATE. Indeed, the magnitude of the point estimate is larger than that for our full sample. However, our NEGI variable enters significantly as well, albeit at only a $10 \%$ confidence level, with the incorrect negative sign. Entering these variables one at a time in columns 5 and 6 , they fail to enter significantly at all.

We therefore conclude that our home country policy effect is more prevalent for the small and medium-sized banks in our sample than it is for large banks. This result is intuitive for both variables: In the case of the home country policy rate, 
TABLE 3. Banks separated by size

Dependent variable: LENDGRWTH

\begin{tabular}{|c|c|c|c|c|c|c|}
\hline VARIABLES & (1) & (2) & (3) & (4) & (5) & (6) \\
\hline POLRATE & $\begin{array}{c}-0.02^{* *} \\
(0.05)\end{array}$ & $\begin{array}{l}-0.05^{*} \\
(0.05)\end{array}$ & & $\begin{array}{c}-0.07^{* * *} \\
(0.00)\end{array}$ & $\begin{array}{c}0.01 \\
(0.34)\end{array}$ & \\
\hline NEGI & $\begin{array}{c}0.12^{* *} \\
(0.02)\end{array}$ & & $\begin{array}{c}0.13^{* *} \\
(0.02)\end{array}$ & $\begin{array}{l}-0.07^{*} \\
(0.05)\end{array}$ & & $\begin{array}{l}-0.02 \\
(0.18)\end{array}$ \\
\hline LOANCOM & $\begin{array}{c}0.03^{* *} \\
(0.01)\end{array}$ & $\begin{array}{c}0.03^{* * *} \\
(0.01)\end{array}$ & $\begin{array}{c}0.03^{* *} \\
(0.01)\end{array}$ & $\begin{array}{c}0.08 \\
(0.36)\end{array}$ & $\begin{array}{c}0.08 \\
(0.42)\end{array}$ & $\begin{array}{c}0.08 \\
(0.41)\end{array}$ \\
\hline COREDEP & $\begin{array}{c}-0.09^{* *} \\
(0.01)\end{array}$ & $\begin{array}{c}-0.09^{* *} \\
(0.03)\end{array}$ & $\begin{array}{c}-0.09^{* *} \\
(0.02)\end{array}$ & $\begin{array}{c}0.17^{* *} \\
(0.05)\end{array}$ & $\begin{array}{c}0.17^{* *} \\
(0.03)\end{array}$ & $\begin{array}{l}0.17^{*} \\
(0.05)\end{array}$ \\
\hline LIQASSET & $\begin{array}{c}0.05 \\
(0.13)\end{array}$ & $\begin{array}{c}0.05 \\
(0.19)\end{array}$ & $\begin{array}{c}0.05 \\
(0.14)\end{array}$ & $\begin{array}{l}-0.28 \\
(0.24)\end{array}$ & $\begin{array}{l}-0.28 \\
(0.24)\end{array}$ & $\begin{array}{l}-0.28 \\
(0.24)\end{array}$ \\
\hline TCAP & $\begin{array}{c}-0.37^{* * *} \\
(0.00)\end{array}$ & $\begin{array}{c}-0.37^{* *} \\
(0.02)\end{array}$ & $\begin{array}{c}-0.37^{* * *} \\
(0.00)\end{array}$ & $\begin{array}{c}0.65 \\
(0.31)\end{array}$ & $\begin{array}{c}0.65 \\
(0.30)\end{array}$ & $\begin{array}{c}0.65 \\
(0.30)\end{array}$ \\
\hline CHGCOREDEP & $\begin{array}{c}-0.69^{* *} \\
(0.01)\end{array}$ & $\begin{array}{c}-0.69^{* *} \\
(0.01)\end{array}$ & $\begin{array}{c}-0.69^{* *} \\
(0.01)\end{array}$ & $\begin{array}{c}-0.23^{* * *} \\
(0.00)\end{array}$ & $\begin{array}{c}-0.23^{* * *} \\
(0.00)\end{array}$ & $\begin{array}{c}-0.23^{* * *} \\
(0.00)\end{array}$ \\
\hline CPIGRWTH & $\begin{array}{l}0.01^{*} \\
(0.05)\end{array}$ & $\begin{array}{l}0.02^{*} \\
(0.07)\end{array}$ & $\begin{array}{c}0.00 \\
(0.15)\end{array}$ & $\begin{array}{c}0.04^{* *} \\
(0.02)\end{array}$ & $\begin{array}{c}0.04^{* *} \\
(0.02)\end{array}$ & $\begin{array}{c}0.04^{* *} \\
(0.03)\end{array}$ \\
\hline USBANK & $\begin{array}{c}0.05^{* *} \\
(0.02)\end{array}$ & $\begin{array}{c}0.01 \\
(0.26)\end{array}$ & $\begin{array}{c}0.06^{* * *} \\
(0.00)\end{array}$ & $\begin{array}{c}0.01 \\
(0.45)\end{array}$ & $\begin{array}{c}0.02 \\
(0.23)\end{array}$ & $\begin{array}{c}0.01 \\
(0.26)\end{array}$ \\
\hline Constant & $\begin{array}{c}0.16^{* * *} \\
(0.00)\end{array}$ & $\begin{array}{c}0.20^{* *} \\
(0.01)\end{array}$ & $\begin{array}{c}0.15^{* * *} \\
(0.00)\end{array}$ & $\begin{array}{l}-0.12 \\
(0.33)\end{array}$ & $\begin{array}{l}-0.14 \\
(0.27)\end{array}$ & $\begin{array}{l}-0.14 \\
(0.30)\end{array}$ \\
\hline Observations & 3,960 & 3,960 & 3,960 & 130 & 130 & 130 \\
\hline R-squared & 0.09 & 0.09 & 0.09 & 0.19 & 0.19 & 0.19 \\
\hline
\end{tabular}

Note: Ordinary least squares estimation of impact of home country policy rates on growth in total loans and leases from 2019Q4 through 2020Q2. Samples split into small and medium-sized banks (assets $<\$ 10 \mathrm{~b}$ ) and large banks (assets $>=\$ 10 \mathrm{~b}$ ). Models 1 through 3 estimate small and medium-sized bank sub-sample, while columns 4 through 6 report results for large bank sub-sample. Standard errors clustered into domestic and foreign subsidiary subgroups. See text for variable definitions. $\mathrm{P}$ values in parenthesis ${ }^{* * *} \mathrm{p}<0.01 ;{ }^{* *} \mathrm{p}<0.05 ;^{*} \mathrm{p}<0.1$

we would expect larger foreign bank subsidiaries to be better-placed to expand or contract their lending portfolio rapidly in response to prevailing interest differentials. The discrepancy in the performance of the NEGI variable is also intuitive. Smaller banks are likely to be more dependent on wholesale deposit funding, where the zerolower bound on interest rates is most biting, and have less capacity for adjustment 
in funding sources as the costs of relative sources of funding changes. As a result, they have been shown to experience greater reductions in net interest income under negative policy rates [e.g. Lopez et al. (2020)].

One last notable discrepancy we find by bank size concerns the performance of our $U S B A N K$ dummy variable. This variable is positive and significant for our small and medium-sized banks in our base specification, but completely insignificant in our large banks sub-sample. ${ }^{6}$ This result is also intuitive, as we would expect more homogeneity in the conditions faced by large domestic banks and foreign bank subsidiaries relative to their smaller counterparts.

V.2. Small business and farm lending growth. The onset of the COVID-19 pandemic in the U.S. in the early weeks of 2020 and the accompanying quarantines and work-from-home orders severely affected the viability of many small businesses, especially those in the retail and service sectors [e.g. Lopez and Spiegel (2021)]. Small businesses play an integral role in the U.S. economy and particularly the labor market, and were the focus of a number of government initiatives aimed at maintaining employment. Most notable of these was the Paycheck Protection Program (PPP), which was launched to help firms retain their employees and cover other ongoing expenses. In this sub-section, we examine how U.S. foreign bank subsidiaries compared to their domestic counterparts in lending to small businesses and farms during the pandemic, as well as the roles played in those outcomes by the home country monetary policies of foreign subsidiaries.

We again use our base specification, but add a variable containing a proxy for bank participation in the PPP program, which we term PPPR. This term measures the share of bank small business and farm lending that was placed under the PPP program. $^{7}$ This program provided guarantees on small business loans. For banks, interest rates were low, but fees collected from the Small Business Administration for

\footnotetext{
${ }^{6}$ Our results with one of the variables of interest for small and medium-sized banks are more mixed, and the USBANK variable continues to enter positively and significantly with the POLRATE variable dropped (Column 3), but becomes insignificant when the NEGI variable is dropped.

${ }^{7}$ As discussed in Lopez and Spiegel (2021), all loans recorded as "small business and farm loans" in the Call Report do not represent what would be commonly considered lending to small businesses. The Call Report defines small business loans as all business loans of $\$ 1$ million or less and small farm loans as farm loans of $\$ 500,000$ or less. It has been documented that these thresholds are potentially noisy indicators of lending to small businesses, as large businesses also take out loans of these small magnitudes.
} 
servicing the loans ended up leaving participation in the PPP program a profitable decision for many banks, particularly on loans considered risky.

Our results are shown in Table 4 . Columns 1 through 3 report the results for growth in small business lending. In our base specification with both variables of interest included, POLRATE comes in with its expected negative coefficient estimate, albeit at only a $10 \%$ confidence level. Moreover, our NEGI variable comes in with the incorrect negative sign, again at only a $10 \%$ confidence level. When entered on their own, POLRATE continues to enter with its predicted negative sign, but only at a $10 \%$ confidence level, and NEGI is now statistically insignificant. Our proxy for participation in the PPP program is very insignificant.

Results for small farm loan growth in columns 4 through 6 provide a similar message. We obtain the expected negative coefficient on the POLRATE variable, in this case at a $5 \%$ confidence level, but the NEGI variable enters with statistical significance with an incorrect negative sign. The $P P P R$ variable again enters insignificantly.

It therefore appears that we cannot make any strong conclusions about the influence of home policy rates or rates below the zero bound on growth in small business and farm lending. This might not be surprising, as small business and farm lending represent only a small component of overall bank lending.

\section{BANK CAPITAL RATIOS AND INCOME}

VI.1. Bank capital asset ratios. In this section, we examine alternative measures of the influence of home country monetary policy on foreign bank subsidiary activity during the pandemic. We first examine the impact of home country policy on bank capital ratios. As we have already seen that low policy rate levels acted to stimulate lending among foreign bank subsidiaries, and that this affect was amplified if home policy rates were below the zero bound, we would expect that this expansion of lending activity would correspond to a reduction in bank capital asset ratios.

We evaluate this question using two alternative measures of bank capital adequacy, $T C A P$, which measures the total capital ratio, and $T 1 R A C A P$, which measures the risk-adjusted capital asset ratio. As before, our dependent variable is the growth in these variables from 2019Q4 to 2020Q2.

Our results are shown in Table 5 . The first three columns report our base regression estimation results with growth in TCAP as the dependent variable. As expected, we obtain a positive and statistically significant coefficient on POLRATE and a negative and significant coefficient estimate on NEGI. Thus, consistent with our expectations, 
TABLE 4. Small business and farm lending growth

Dependent variable: Growth in small business and farm lending as indicated below

\begin{tabular}{|c|c|c|c|c|c|c|}
\hline & $\begin{array}{c}(1) \\
\text { Business }\end{array}$ & $\begin{array}{c}(2) \\
\text { Business }\end{array}$ & $\begin{array}{c}(3) \\
\text { Business }\end{array}$ & $\begin{array}{c}(4) \\
\text { Farm }\end{array}$ & $\begin{array}{c}(5) \\
\text { Farm }\end{array}$ & $\begin{array}{c}(6) \\
\text { Farm }\end{array}$ \\
\hline POLRATE & $\begin{array}{c}-0.09^{*} \\
(0.07)\end{array}$ & $\begin{array}{c}-0.07^{*} \\
(0.10)\end{array}$ & & $\begin{array}{c}-0.11^{* *} \\
(0.01)\end{array}$ & $\begin{array}{c}-0.04^{* *} \\
(0.02)\end{array}$ & \\
\hline NEGI & $\begin{array}{c}-0.08^{* *} \\
(0.01)\end{array}$ & & $\begin{array}{l}-0.01 \\
(0.45)\end{array}$ & $\begin{array}{c}-0.21^{* * *} \\
(0.01)\end{array}$ & & $\begin{array}{c}-0.17^{* *} \\
(0.02)\end{array}$ \\
\hline LGBANK & $\begin{array}{c}0.14 \\
(0.11)\end{array}$ & $\begin{array}{c}0.14 \\
(0.11)\end{array}$ & $\begin{array}{c}0.14 \\
(0.14)\end{array}$ & $\begin{array}{c}0.02 \\
(0.29)\end{array}$ & $\begin{array}{c}0.02 \\
(0.22)\end{array}$ & $\begin{array}{c}0.02 \\
(0.34)\end{array}$ \\
\hline LOANCOM & $\begin{array}{c}0.05 \\
(0.11)\end{array}$ & $\begin{array}{c}0.05 \\
(0.11)\end{array}$ & $\begin{array}{c}0.04 \\
(0.11)\end{array}$ & $\begin{array}{l}-0.03^{*} \\
(0.05)\end{array}$ & $\begin{array}{c}-0.03^{* *} \\
(0.05)\end{array}$ & $\begin{array}{l}-0.03^{*} \\
(0.06)\end{array}$ \\
\hline COREDEP & $\begin{array}{c}-0.33^{* *} \\
(0.03)\end{array}$ & $\begin{array}{c}-0.33^{* *} \\
(0.03)\end{array}$ & $\begin{array}{c}-0.33^{* *} \\
(0.04)\end{array}$ & $\begin{array}{l}0.08^{*} \\
(0.06)\end{array}$ & $\begin{array}{l}0.08^{*} \\
(0.06)\end{array}$ & $\begin{array}{c}0.08^{* *} \\
(0.02)\end{array}$ \\
\hline LIQASSET & $\begin{array}{l}-0.01 \\
(0.75)\end{array}$ & $\begin{array}{l}-0.01 \\
(0.75)\end{array}$ & $\begin{array}{l}-0.01 \\
(0.76)\end{array}$ & $\begin{array}{l}0.02^{*} \\
(0.06)\end{array}$ & $\begin{array}{c}0.02^{* *} \\
(0.05)\end{array}$ & $\begin{array}{l}0.02^{*} \\
(0.07)\end{array}$ \\
\hline TCAP & $\begin{array}{c}-0.94^{* *} \\
(0.03)\end{array}$ & $\begin{array}{c}-0.94^{* *} \\
(0.03)\end{array}$ & $\begin{array}{c}-0.95^{* *} \\
(0.04)\end{array}$ & $\begin{array}{l}-0.06 \\
(0.33)\end{array}$ & $\begin{array}{l}-0.06 \\
(0.25)\end{array}$ & $\begin{array}{l}-0.07 \\
(0.19)\end{array}$ \\
\hline CHGCOREDEP & $\begin{array}{c}-1.36^{* *} \\
(0.02)\end{array}$ & $\begin{array}{c}-1.36^{* *} \\
(0.02)\end{array}$ & $\begin{array}{c}-1.36^{* *} \\
(0.02)\end{array}$ & $\begin{array}{c}0.02^{* *} \\
(0.02)\end{array}$ & $\begin{array}{l}0.02^{*} \\
(0.07)\end{array}$ & $\begin{array}{c}0.02^{* * *} \\
(0.00)\end{array}$ \\
\hline CPIGRWTH & $\begin{array}{c}-0.04^{* *} \\
(0.05)\end{array}$ & $\begin{array}{c}-0.05^{* *} \\
(0.04)\end{array}$ & $\begin{array}{c}-0.08^{* * *} \\
(0.00)\end{array}$ & $\begin{array}{c}0.06^{* * *} \\
(0.01)\end{array}$ & $\begin{array}{c}0.04^{* * *} \\
(0.01)\end{array}$ & $\begin{array}{l}-0.00 \\
(0.14)\end{array}$ \\
\hline USBANK & $\begin{array}{c}-0.09^{*} \\
(0.09)\end{array}$ & $\begin{array}{l}-0.07 \\
(0.11)\end{array}$ & $\begin{array}{l}-0.05 \\
(0.12)\end{array}$ & $\begin{array}{c}-0.07^{*} \\
(0.05)\end{array}$ & $\begin{array}{l}-0.00 \\
(0.92)\end{array}$ & $\begin{array}{l}-0.04 \\
(0.11)\end{array}$ \\
\hline PPPR & $\begin{array}{c}0.01 \\
(0.13)\end{array}$ & $\begin{array}{c}0.01 \\
(0.13)\end{array}$ & $\begin{array}{c}0.01 \\
(0.13)\end{array}$ & $\begin{array}{l}-0.00 \\
(0.12)\end{array}$ & $\begin{array}{l}-0.00 \\
(0.16)\end{array}$ & $\begin{array}{l}-0.00 \\
(0.13)\end{array}$ \\
\hline Constant & $\begin{array}{c}0.83^{* * *} \\
(0.01)\end{array}$ & $\begin{array}{c}0.80^{* * *} \\
(0.01)\end{array}$ & $\begin{array}{c}0.79 * * \\
(0.01)\end{array}$ & $\begin{array}{l}-0.01 \\
(0.59)\end{array}$ & $\begin{array}{l}-0.08 \\
(0.12)\end{array}$ & $\begin{array}{l}-0.03 \\
(0.23)\end{array}$ \\
\hline Observations & 3,840 & 3,840 & 3,840 & 3,363 & 3,363 & 3,363 \\
\hline R-squared & 0.05 & 0.05 & 0.05 & 0.00 & 0.00 & 0.00 \\
\hline
\end{tabular}

$\mathrm{P}$ value in parenthesis

Note: Ordinary least squares estimation of impact of home country policy rates on growth in small business and farm lending from 2019Q4 through 2020Q2. Models 1 through 3 estimate small business lending growth and columns 4 through 6 report results for small farm lending growth. Standard errors clustered into domestic and foreign subsidiary subgroups. See text for variable definitions. P values in parenthesis $* * * \mathrm{p}<0.01 ; * * \mathrm{p}<0.05 ;{ }^{*} \mathrm{p}<0.1$ 
easier home country monetary policy is associated with increased bank activity and deterioration in foreign bank subsidiary balance sheets. However, these estimated movements in bank capital asset ratios are not large. Our point estimates indicate that a one standard deviation decrease in POLRATE is associated with only an 88 basis point deterioration in total bank capital ratios. We do get a larger estimate for the effect of going into negative policy rate territory. A negative home country policy rate is estimated to add another 3 percentage points to the decline in the total capital asset ratio. As before, repeating our specification with the variables of interest included one at a time yields similar results, with modestly larger point estimates.

The latter three columns repeat our base specification using the risk-adjusted tier 1 capital ratio. In particular, as loans extended under the Paycheck Protection Program were guaranteed by the U.S. Treasury, they were assigned a 0 risk weight in riskadjusted capital ratio measures by regulatory authorities. Indeed, Lopez and Spiegel (2021) demonstrate that while greater growth in bank small business lending in 2021 was associated with a deterioration in total capital ratios, the same pattern was also associated with increases in measured bank tier 1 risk-adjusted capital ratios.

However, particularly for larger global banks, it is unlikely that a large portion of lending activity was influenced by this program, as small business lending comprises a relatively small portion of overall foreign bank subsidiary lending packages. Indeed, our results for POLRATE indicate that easier home country monetary policies are associated with even greater deterioration among risk-adjusted capital ratios. Our point estimates indicate that a one standard deviation decrease in home country policy rates is associated with a 6.1 percentage point decline in growth in foreign bank subsidiary tier 1 risk-adjusted capital ratios.

The results for negative home country policy rates are weaker. In our base specification, with both variables of interest entered simultaneously, our coefficient estimate for NEGI is insignificant and close to zero. Entered on its own (column 6), we find that negative home country policy rates are associated with 5 percentage points lower growth in risk-adjusted capital asset ratios on average.

VI.2. Bank income. The increased lending activity associated with easier home country monetary policy would also be expected to result in increased bank income over the period. We evaluate this effect in Table 6 .

Columns 1 through 3 repeat our base specification with growth in net income as a dependent variable. Our results are consistent with the hypothesis that easier monetary policy was associated with increased foreign bank subsidiary lending activity, 
TABLE 5. Capital asset ratio growth

Dependent variable: Growth in capital ratio measure indicated below

\begin{tabular}{|c|c|c|c|c|c|c|}
\hline & $\begin{array}{c}(1) \\
\text { TCAP }\end{array}$ & $\begin{array}{c}(2) \\
\text { TCAP }\end{array}$ & $\begin{array}{c}(3) \\
\text { TCAP }\end{array}$ & $\begin{array}{c}(4) \\
\text { T1RACAP }\end{array}$ & $\begin{array}{c}(5) \\
\text { T1RACAP }\end{array}$ & $\begin{array}{c}(6) \\
\text { T1RACAP }\end{array}$ \\
\hline VARIABLES & & & & & & \\
\hline POLRATE & $\begin{array}{c}0.01^{* *} \\
(0.01)\end{array}$ & $\begin{array}{c}0.02^{* * *} \\
(0.01)\end{array}$ & & $\begin{array}{c}0.07^{* *} \\
(0.04)\end{array}$ & $\begin{array}{c}0.07^{* *} \\
(0.05)\end{array}$ & \\
\hline NEGI & $\begin{array}{c}-0.03^{* * *} \\
(0.00)\end{array}$ & & $\begin{array}{c}-0.04^{* * *} \\
(0.00)\end{array}$ & $\begin{array}{c}0.00 \\
(0.36)\end{array}$ & & $\begin{array}{c}-0.05^{*} \\
(0.08)\end{array}$ \\
\hline LGBANK & $\begin{array}{l}-0.04^{*} \\
(0.07)\end{array}$ & $\begin{array}{c}-0.04^{*} \\
(0.07)\end{array}$ & $\begin{array}{l}-0.04^{*} \\
(0.08)\end{array}$ & $\begin{array}{c}0.35^{* *} \\
(0.05)\end{array}$ & $\begin{array}{c}0.35^{* *} \\
(0.05)\end{array}$ & $\begin{array}{l}0.34^{*} \\
(0.06)\end{array}$ \\
\hline LOANCOM & $\begin{array}{c}-0.02^{* *} \\
(0.02)\end{array}$ & $\begin{array}{c}-0.02^{* *} \\
(0.02)\end{array}$ & $\begin{array}{c}-0.02^{* *} \\
(0.02)\end{array}$ & $\begin{array}{c}0.03^{* *} \\
(0.04)\end{array}$ & $\begin{array}{c}0.03^{* *} \\
(0.04)\end{array}$ & $\begin{array}{c}0.03^{* *} \\
(0.04)\end{array}$ \\
\hline COREDEP & $\begin{array}{c}0.02 \\
(0.16)\end{array}$ & $\begin{array}{c}0.02 \\
(0.14)\end{array}$ & $\begin{array}{c}0.02 \\
(0.13)\end{array}$ & $\begin{array}{c}-0.47^{* *} \\
(0.02)\end{array}$ & $\begin{array}{c}-0.47^{* *} \\
(0.02)\end{array}$ & $\begin{array}{c}-0.46^{* *} \\
(0.02)\end{array}$ \\
\hline LIQASSET & $\begin{array}{c}0.00^{* * *} \\
(0.01)\end{array}$ & $\begin{array}{l}0.00^{*} \\
(0.10)\end{array}$ & $\begin{array}{c}0.00 \\
(0.11)\end{array}$ & $\begin{array}{l}0.19^{*} \\
(0.06)\end{array}$ & $\begin{array}{l}0.19^{*} \\
(0.06)\end{array}$ & $\begin{array}{l}0.19^{*} \\
(0.07)\end{array}$ \\
\hline TCAP & $\begin{array}{l}-0.02 \\
(0.61)\end{array}$ & $\begin{array}{l}-0.02 \\
(0.63)\end{array}$ & $\begin{array}{l}-0.02 \\
(0.60)\end{array}$ & $\begin{array}{c}-1.50^{* *} \\
(0.05)\end{array}$ & $\begin{array}{c}-1.50^{* *} \\
(0.05)\end{array}$ & $\begin{array}{c}-1.50^{* *} \\
(0.05)\end{array}$ \\
\hline CHGCOREDEP & $\begin{array}{c}0.19^{* *} \\
(0.05)\end{array}$ & $\begin{array}{c}0.19^{* *} \\
(0.05)\end{array}$ & $\begin{array}{c}0.19^{* *} \\
(0.05)\end{array}$ & $\begin{array}{c}-0.17^{* * *} \\
(0.00)\end{array}$ & $\begin{array}{c}-0.17^{* * *} \\
(0.00)\end{array}$ & $\begin{array}{c}-0.17^{* * *} \\
(0.00)\end{array}$ \\
\hline CPIGRWTH & $\begin{array}{c}0.00 \\
(0.12)\end{array}$ & $\begin{array}{c}0.00 \\
(0.34)\end{array}$ & $\begin{array}{c}0.01^{* *} \\
(0.03)\end{array}$ & $\begin{array}{c}-0.01^{* *} \\
(0.05)\end{array}$ & $\begin{array}{l}-0.01^{*} \\
(0.05)\end{array}$ & $\begin{array}{c}0.02^{* *} \\
(0.04)\end{array}$ \\
\hline USBANK & $\begin{array}{c}-0.02^{* *} \\
(0.02)\end{array}$ & $\begin{array}{c}-0.01^{* *} \\
(0.04)\end{array}$ & $\begin{array}{c}-0.03^{* * *} \\
(0.00)\end{array}$ & $\begin{array}{c}-0.13^{* *} \\
(0.03)\end{array}$ & $\begin{array}{c}-0.13^{* *} \\
(0.03)\end{array}$ & $\begin{array}{c}-0.16^{* *} \\
(0.02)\end{array}$ \\
\hline Constant & $\begin{array}{c}-0.05^{* * *} \\
(0.01)\end{array}$ & $\begin{array}{c}-0.06^{* * *} \\
(0.00)\end{array}$ & $\begin{array}{c}-0.05^{* * *} \\
(0.01)\end{array}$ & $\begin{array}{c}0.31^{* *} \\
(0.03)\end{array}$ & $\begin{array}{c}0.31^{* *} \\
(0.03)\end{array}$ & $\begin{array}{c}0.34^{* *} \\
(0.03)\end{array}$ \\
\hline Observations & 4,109 & 4,109 & 4,109 & 4,109 & 4,109 & 4,109 \\
\hline R-squared & 0.03 & 0.03 & 0.03 & 0.03 & 0.03 & 0.03 \\
\hline
\end{tabular}

Note: Ordinary least squares estimation of impact of home country policy rates on growth in capital ratios from 2019Q4 through 2020Q2. Models 1 through 3 estimate total capital ratio growth, while columns 4 through 6 report results for tier-1 risk-adjusted capital ratio growth. Standard errors clustered into domestic and foreign subsidiary subgroups. See text for variable definitions. $\mathrm{P}$ values in parenthesis $* * * \mathrm{p}<0.01 ; * *$ $\mathrm{p}<0.05 ;{ }^{*} \mathrm{p}<0.1$ 
and hence income, over this period. POLRATE enters negatively with significance at a $5 \%$ confidence level, indicating that easier home country monetary policy was associated with increased foreign bank subsidiary income. Our point estimate indicates that a one standard deviation decrease in home country policy rates was associated with a 5.3 percentage point increase in net income growth over the first half of 2020 . We obtain more mixed results for the $N E G I$ variable, as the variable enters with a very small coefficient point estimate with both POLRATE and NEGI included together, but on its own with a point estimate that indicates that a negative home country policy rate was associated with 5 percentage points higher income growth on average over the first half of 2020 .

Columns 4 and 5 substitute growth in the primary components of net income, net interest income and net non-interest income respectively. Interestingly, these components behave very differently, both from each other and within each for our two indicators of home country monetary policy.

For net interest income, POLRATE enters negatively, with statistical significance at a $10 \%$ confidence level. Our coefficient point estimate suggests that a one standard deviation decrease in home country policy rates is associated with a 4.4 percentage point increase in growth in net interest income. However, we also obtain a negative coefficient point estimate on NEGI, which enters significantly at a $5 \%$ confidence level, and indicates that after accounting for differences in interest rate levels, foreign subsidiaries with negative home country policy rates experienced on average one percentage point lower growth in net interest income.

In contrast, we obtain opposite signed coefficients for net non-interest income. POLRATE enters positively and with statistical significance at a $5 \%$ confidence level, while NEGI also enters positively and signfiicantly at a $1 \%$ confidence level. Our point estimates indicate that a one standard deviation decrease in home country policy rates are associated with a 3.5 percentage point increase in non-interest income, while negative home country rates holding all else constant are associated with an 8 percentage point increase in non-interest income.

These mixed results appear to reflect the complicated funding and revenue options available to foreign bank subsidiaries in the United States. Discrepancies between interest and non-interest income performances under negative rates have been documented in the literature [e.g. Lopez et al. (2020)], as banks have often responded to losses on interest income in the United States by increasing non-interest income through fees on deposits and other service vehicles. This seems consistent with the 
TABLE 6. Income growth

Dependent variable: Growth in income measure indicated below

\begin{tabular}{|c|c|c|c|c|c|}
\hline & $(1)$ & $(2)$ & $(3)$ & (4) & (5) \\
\hline & INC & INC & INC & NIINC & NNIINC \\
\hline \multicolumn{6}{|l|}{ VARIABLES } \\
\hline \multirow[t]{2}{*}{ POLRATE } & $-0.06^{* *}$ & $-0.06^{* *}$ & & $-0.05^{*}$ & $0.04^{* *}$ \\
\hline & $(0.03)$ & $(0.02)$ & & $(0.07)$ & $(0.04)$ \\
\hline \multirow[t]{2}{*}{ NEGI } & $0.00^{*}$ & & $0.05^{* *}$ & $-0.01^{* *}$ & $0.08^{* * *}$ \\
\hline & $(0.06)$ & & $(0.04)$ & $(0.04)$ & $(0.00)$ \\
\hline \multirow[t]{2}{*}{ LGBANK } & $-0.05^{* *}$ & $-0.05^{* *}$ & $-0.05^{*}$ & $-0.06^{* *}$ & 0.04 \\
\hline & $(0.05)$ & $(0.05)$ & $(0.10)$ & $(0.04)$ & $(0.23)$ \\
\hline \multirow[t]{2}{*}{ LOANCOM } & 0.01 & 0.01 & 0.01 & $0.02^{* *}$ & 0.00 \\
\hline & $(0.11)$ & $(0.10)$ & $(0.12)$ & $(0.02)$ & $(0.19)$ \\
\hline \multirow[t]{2}{*}{ COREDEP } & $-0.08^{*}$ & $-0.08^{*}$ & $-0.08^{*}$ & $-0.15^{* * *}$ & $0.16^{*}$ \\
\hline & $(0.06)$ & $(0.06)$ & $(0.08)$ & $(0.01)$ & $(0.07)$ \\
\hline \multirow[t]{2}{*}{ LIQASSET } & $-0.09 * *$ & $-0.09^{* *}$ & $-0.09^{* *}$ & $-0.16^{* *}$ & $-0.08^{* *}$ \\
\hline & $(0.01)$ & $(0.01)$ & $(0.01)$ & $(0.03)$ & $(0.01)$ \\
\hline \multirow[t]{2}{*}{ TCAP } & $-0.16^{*}$ & $-0.16^{*}$ & $-0.16^{*}$ & -0.35 & -0.07 \\
\hline & $(0.06)$ & $(0.06)$ & $(0.07)$ & $(0.13)$ & $(0.21)$ \\
\hline \multirow[t]{2}{*}{ CHGCOREDEP } & $-0.26^{* * *}$ & $-0.26^{* * *}$ & $-0.26^{* * *}$ & $-0.34^{* * *}$ & $0.13^{*}$ \\
\hline & $(0.01)$ & $(0.01)$ & $(0.01)$ & $(0.01)$ & $(0.08)$ \\
\hline \multirow[t]{2}{*}{ CPIGRWTH } & $0.02^{* *}$ & $0.02^{* *}$ & -0.00 & 0.01 & $0.01 * * *$ \\
\hline & $(0.03)$ & $(0.03)$ & $(0.31)$ & $(0.20)$ & $(0.00)$ \\
\hline \multirow[t]{2}{*}{ USBANK } & $0.05^{* *}$ & $0.05^{* *}$ & $0.07^{* *}$ & 0.02 & $-0.03^{*}$ \\
\hline & $(0.05)$ & $(0.05)$ & $(0.04)$ & $(0.26)$ & $(0.08)$ \\
\hline \multirow[t]{2}{*}{ Constant } & $0.03^{* *}$ & $0.04^{* *}$ & 0.01 & $0.22 *$ & $-0.16^{*}$ \\
\hline & $(0.01)$ & $(0.01)$ & $(0.13)$ & $(0.05)$ & $(0.06)$ \\
\hline Observations & 4,109 & 4,109 & 4,109 & 4,109 & 4,108 \\
\hline R-squared & 0.04 & 0.04 & 0.04 & 0.06 & 0.01 \\
\hline
\end{tabular}

Note: Ordinary least squares estimation of impact of home country policy rates on growth in income from 2019Q4 through 2020Q2. Models 1 through 3 estimate impact on growth in net income, while column 4 estimates impact on growth in net interest income and column 5 reports estimates of impact on net non-interest income. Standard errors clustered into domestic and foreign subsidiary subgroups. See text for variable definitions. $\mathrm{P}$ values in parenthesis ${ }^{* * *} \mathrm{p}<0.01{ }^{* *} \mathrm{p}<0.05 ;^{*} \mathrm{p}<0.1$

negative point estimate on $N E G I$ for interest income growth, and the positive one on non-interest income growth. 
However, by definition, foreign bank subsidiaries in the United States raise funds domestically, and indeed have been shown to rely on domestic deposits at rates comparable to their domestic competitors (e.g. Goulding and Nolle (2012)). As such, one might be surprised to see this effect displayed in the data. This might explain the conflicting picture obtained for the income components for policy rate changes. There, we obtain results that would be more akin to the expected response of domestic banks, as lower home country policy rates, if interpreted more generally as a positive shock to internal capital, would be expected to increase lending activity and therefore interest income, likely at the expense of non-interest income.

\section{CONCLUSION}

This paper examines global monetary policy spillovers through a comparison of the lending practices of U.S. foreign bank subsidiaries and their domestic counterparts during the first half of 2020. Our results confirm that the lending channel was a feature of this period, as foreign subsidiaries responded to both home country policy rate levels and rates below the zero bound by increasing their lending activity in the United States. Our results were strongest for small and medium-sized banks. Large foreign subsidiaries were less sensitive to home country monetary policy conditions. As easier home monetary policy conditions encouraged increased U.S. activity, banks also exited the pandemic period with lower capital ratios.

The implications of this expansion on income, however, was more mixed. Easier policy rates were found to expand net income, but the implications of negative rates were more mixed. The estimated impact of negative rates on net income was close to zero, while that on its components of interest and non-interest income were positive and negative respectively. This latter finding seems to mirror findings in the literature for domestic banks under negative policy rates, as banks moved out of less-profitable traditional banking activity to rely more heavily on other revenue vehicles and fees.

However, the overall message of the paper is that the bank lending channel for global monetary policy spillovers that was identified during the global financial crisis appears to have also influenced credit dynamics during the pandemic. An important caveat, however, is that much was held constant in our analysis. In particular, we do not account for the impacts of home country regulatory policy or implicit government guarantees on lending embedded in panedmic policy responses. These differed widely across the home countries in our sample. 


\section{TABle A1. Foreign Bank Sample}

\begin{tabular}{|c|c|c|}
\hline Bank Name & Parent Country & Policy Rate \\
\hline City National Bank & Canada & .25 \\
\hline Delta Bank and Trust Company & Cayman Islands & .1 \\
\hline BMO Harris Bank & Canada & .25 \\
\hline Bank Leumi USA & Israel & .1 \\
\hline Banco do Brasil Americas & Brazil & 2.25 \\
\hline Flagstar Bank & Cayman Islands & .1 \\
\hline MUFG Union Bank & Japan & -.068 \\
\hline Deutsche Bank USA & Germany & -.5 \\
\hline Mizuho Bank USA & Japan & -.068 \\
\hline Habib American Bank & Switzerland & -.75 \\
\hline Oriental Bank & Puerto Rico & .125 \\
\hline Deutsche Bank Trust Co. Delaware & Germany & -.5 \\
\hline Israel Discount Bank of New York & Israel & .1 \\
\hline BankPacific & Guam & .125 \\
\hline Woori America Bank & South Korea & .5 \\
\hline HSBC Bank USA & United Kingdom & .1 \\
\hline TD Bank & Canada & .25 \\
\hline FirstBank Puerto Rico & Puerto Rico & .125 \\
\hline KEB Hana Bank USA & South Korea & .5 \\
\hline BBVA USA & Spain & -.5 \\
\hline Bank of Guam & Guam & .125 \\
\hline Santander Bank & Spain & -.5 \\
\hline BAC Florida Bank & Brazil & 2.25 \\
\hline State Bank of India - California & India & 4 \\
\hline Bank of the West & France & -.5 \\
\hline City National Bank of Florida & Chile & .5 \\
\hline Safra National Bank of New York & Gibraltar & .1 \\
\hline Sumitomo Mitsui Trust Bank USA & Japan & -.068 \\
\hline Manufacturers Bank & Japan & -.068 \\
\hline Banco Popular de Puertro Rico & Puerto Rico & .125 \\
\hline CTBC Bank Corp. USA & Taiwan & 1.125 \\
\hline Industrial and Commercial Bank of China & China & 2.25 \\
\hline Shinhan Bank America & South Korea & .5 \\
\hline Canadian Imperical Bank of Commerce U.S. & Canada & .25 \\
\hline ANZ in Guam & Australia & .25 \\
\hline Desjardins Bank & Canada & .25 \\
\hline TD Bank USA & Canada & .25 \\
\hline Natbank & Canada & .25 \\
\hline EverTrust Bank & Taiwan & 1.125 \\
\hline First Commercial Bank USA & Taiwan & 1.125 \\
\hline Popular Bank & Puerto Rico & .125 \\
\hline BMW Bank of North America & Germany & -.5 \\
\hline Barclays Bank Delaware & United Kingdom & .1 \\
\hline UBS Bank USA & Switzerland & -.75 \\
\hline Toyota Financial Savings Bank & Japan & -.068 \\
\hline RBC Bank Georgia & Canada & .25 \\
\hline
\end{tabular}


TABle A2. Positive and negative policy rate foreign bank statistics

\begin{tabular}{|c|c|c|c|c|}
\hline & \multicolumn{4}{|c|}{ Negi $=1$} \\
\hline & mean & $\mathrm{sd}$ & $\min$ & $\max$ \\
\hline LENDGRWTH & 0.09 & 0.13 & -0.03 & 0.36 \\
\hline T1RCAP & -0.10 & 0.13 & -0.34 & 0.09 \\
\hline POLRATE & -0.37 & 0.27 & -0.75 & -0.07 \\
\hline NEGI & 1.00 & 0.00 & 1.00 & 1.00 \\
\hline LGBANK & 0.54 & 0.52 & 0.00 & 1.00 \\
\hline LOANCOM & 0.09 & 0.13 & 0.00 & 0.47 \\
\hline COREDEP & 0.71 & 0.23 & 0.03 & 0.90 \\
\hline LIQASSET & 0.27 & 0.34 & 0.02 & 0.98 \\
\hline TCAP & 0.21 & 0.23 & 0.09 & 0.94 \\
\hline CHGCOREDEP & 0.02 & 0.04 & -0.06 & 0.07 \\
\hline CPIGRWTH & -0.07 & 0.68 & -1.22 & 0.76 \\
\hline \multirow[t]{3}{*}{ Observations } & 13 & & & \\
\hline & \multicolumn{4}{|c|}{ Negi $=0$} \\
\hline & mean & $\mathrm{sd}$ & $\min$ & $\max$ \\
\hline LENDGRWTH & 0.06 & 0.07 & -0.04 & 0.23 \\
\hline T1RCAP & -0.05 & 0.08 & -0.27 & 0.10 \\
\hline POLRATE & 0.60 & 0.88 & 0.10 & 4.00 \\
\hline NEGI & 0.00 & 0.00 & 0.00 & 0.00 \\
\hline LGBANK & 0.36 & 0.49 & 0.00 & 1.00 \\
\hline LOANCOM & 0.05 & 0.08 & 0.00 & 0.39 \\
\hline COREDEP & 0.81 & 0.06 & 0.69 & 0.89 \\
\hline LIQASSET & 0.11 & 0.14 & 0.01 & 0.77 \\
\hline TCAP & 0.14 & 0.03 & 0.09 & 0.20 \\
\hline CHGCOREDEP & -0.00 & 0.04 & -0.11 & 0.06 \\
\hline CPIGRWTH & 0.43 & 1.45 & -1.09 & 5.20 \\
\hline Observations & 33 & & & \\
\hline
\end{tabular}

Note: Dependent variable: Growth in small business and farm lending from 2019Q4 through 2020Q2. Instrumental variables estimation. See text for variable definitions and column specifications. ${ }^{* * *} \mathrm{p}<0.01$; ** $\mathrm{p}<0.05 ;{ }^{*} \mathrm{p}<0.1$ 


\section{REFERENCES}

Acharya, V. V., G. Afonso, and A. Kovner (2017). How do global banks scramble for liquidity? evidence from the asset-backed commercial paper freeze of 2007. Journal of Financial Intermediation 30, 1-34.

Albertazzi, U. and M. Bottero (2014). Foreign bank lending: Evidence from the global financial crisis. Journal of International Economics 92, S22-S35.

Altavilla, C., M. Boucinha, and J.-L. Peydró (2018). Monetary policy and bank profitability in a low interest rate environment. Economic Policy, 533-586.

Anbil, S., M. Carlson, and M. Styczynski. The effect of the PPPLF on PPP lending by commercial banks. mimeo.

Ashraf, B. N. and S. Arshad (2017). Foreign bank subsidiaries' risk-taking behavior: Impact of home and host country national culture. Research in International Business and Finance 41, 318-335.

Avdjiev, S., B. Hardy, P. McGuire, and G. von Peter (2021). Home sweet host: A cross-country perspective on prudential and monetary policy spillovers through global banks. Review of International Economics 29(1), 20-36.

Berger, A. N., C. H. Bouwman, L. Norden, R. A. Roman, G. F. Udell, and T. Wang. Is a friend in need a friend indeed? how relationship borrowers fare during the covid-19 crisis. mimeo.

Berrospide, J. M., R. Correa, L. S. Goldberg, and F. Niepmann (2017, March). International banking and cross-border effects of regulation Lessons from the united states. International Journal of Central Banking, 435-476.

Borio, C. and L. Gambacorta (2017). Monetary policy and bank lending in a low interest rate environment: diminishing effectiveness? Journal of Macroeconomics 54(8), $217-231$.

Bottero, M., C. Minoiu, J.-L. Peydro, A. Polo, A. F. Presbitero, and E. Sette. Negative monetary policy rates and portfolio rebalancing: Evidence from credit register data. IMF Working Paper WP/19/44.

Buch, C. M., M. Bussierè, L. Goldberg, and R. Hills (2019). The international transmission of monetary policy. Journal of International Money and Finance 91, 29-48. Bussierè, M., J. Cao, J. de Haan, R. Hills, S. Lloyd, B. Meunier, J. Pedrono, D. Reinhardt, S. Sinha, R. Sowerbutts, and K. Styrin (2021). The interaction between marcoprudential policy and monetary policy: Overview. Review of International Economics 29(1), 1-19. 
Cettorelli, N. and L. S. Goldberg (2011). Global banks and international shock transmission: Evidence from the crisis. International Monetary Fund Economic Review $59(1), 41-76$.

Cettorelli, N. and L. S. Goldberg (2012a). Banking globalization and monetary transmission. The Journal of Finance 67(5), 1811-1843.

Cettorelli, N. and L. S. Goldberg (2012b). Liquidity management of u.s. global banks: Internal capital markets in the great recession. Journal of International Economics 88, 299-311.

Cornett, M. M., J. McNutt, P. E. Strahan, and H. Tehranian (2011). Liquidity risk management and credit supply in the financial crisis. Journal of Financial Economics 101(2), 297-312.

Dekle, R. and M. Lee (2015). Do foreign bank affiliates cut their lending more than the domestic banks in a financial crisis? Journal of International Money and Finance 50, 16-32.

Demiralp, S., J. Eisenschmidt, and T. Vlassopoulos (2019, May). Negative interest rates, excess liquidity, and bank business models: Banks' reaction to unconventional monetary policy in the euro area. ECB Working Paper no 2283.

Demirgüç-Kunt, A., B. L. Horváth, and H. Huizinga (2017, January). Foreign banks and international transmission of monetary policy. World Bank Policy Research Working Paper no. 7937.

di Giovanni, J., S. Kalemli-Özcan, M. F. Ulu, and Y. S. Baskaya (2018, September). International spillovers and local credit cycles. mimeo.

Goldberg, L. G. and A. Saunders (1981). The determinants of foreign banking activity in the united states. Journal of Banking and Finance 5(1), 17-32.

Goulding, W. and D. E. Nolle (2012, November). Foreign banks in the u.s.: A primer. Board of Governors of the Federal Reserve System International Finance Discussion Papers Number 1064.

Greenwald, D. L., J. Krainer, and P. Paul (2020, November). The credit line channel. FRBSF Working Paper No. 2020-26.

Hardy, B. and E. Takáts (2020). International banking amidst Covid-19: resilience and drivers. BIS Quarterly Review.

Houston, J. F., C. Lin, and Y. Ma (2012). Regulatory arbitrage and international bankflows. Journal of Finance 67(5), 1845-1895.

Kleimeier, S., H. Sander, and S. Heuchemer (2013). Financial crises and cross-border banking New evidence. Journal of International Money and Finance 32, 884-915. 
Li, L. and P. Strahan (2020). Who supplies ppp loans (and does it matter): Banks, relationships, and the covid crisis. NBER Working Paper 28286.

Lopez, J. A., A. K. Rose, and M. M. Spiegel (2020). Why have negative nominal interest rates had such a small effect on bank performance? cross country evidence. European Economic Review 124, 1-17.

Lopez, J. A. and M. M. Spiegel (2021, March). Small business lending under the PPP and PPPLF programs. Federal Reserve Bank of San Francisco Working Paper $2021-10$.

Ongena, S., J. L. Peydro, and N. V. Horen (2015). Shocks abroad, pain at home? bank firm level evidence on the international transmission of financial shocks. IMF Economic Review 63(4), 216-225.

Peek, J. and E. S. Rosengren (1997). The international transmission of financial shocks: The case of japan. American Economic Review 87, 495-505.

Rai, A., R. Seth, and S. K. Mohanty (2021). Foreign bank lending in the U.S. during three U.S. recessions. Global Finance Journal 48, 1-15.

Rice, T. and J. Rose (2016). When good investments go bad: The contraction in community bank lending after the 2008 GSE takeover. Journal of Financial Intermediation 27, 68-88.

Takáts, E. and J. Temesvary (2019, May). How does the interaction of macroprudential and monetary policies affect cross-border bank lending? Finance and Economics Discussion Series 2019-45.

Ulate, M. (2021). Going negative at the zero lower bound: The effects of negative nominal interest rates. American Economic Review 111(1), 1-40. 